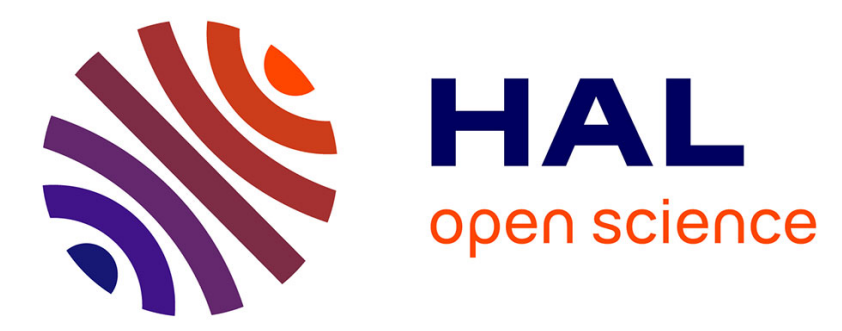

\title{
Synthesis of nanostructured materials in supercritical ammonia: nitrides, metals and oxides
}

\author{
Sophie Desmoulins-Krawiec, Cyril Aymonier, Anne Loppinet-Serani, François \\ Weill, Stéphane Gorsse, Jean Etourneau, François Cansell
}

\section{- To cite this version:}

Sophie Desmoulins-Krawiec, Cyril Aymonier, Anne Loppinet-Serani, François Weill, Stéphane Gorsse, et al.. Synthesis of nanostructured materials in supercritical ammonia: nitrides, metals and oxides. Journal of Materials Chemistry, 2004, 14 (2), pp.228-232. 10.1039/b310806f . hal-00136091

\section{HAL Id: hal-00136091 https://hal.science/hal-00136091}

Submitted on 19 Mar 2009

HAL is a multi-disciplinary open access archive for the deposit and dissemination of scientific research documents, whether they are published or not. The documents may come from teaching and research institutions in France or abroad, or from public or private research centers.
L'archive ouverte pluridisciplinaire HAL, est destinée au dépôt et à la diffusion de documents scientifiques de niveau recherche, publiés ou non, émanant des établissements d'enseignement et de recherche français ou étrangers, des laboratoires publics ou privés. 


\title{
Synthesis of nanostructured materials in supercritical ammonia: nitrides, metals and oxides
}

\author{
Desmoulins-Krawiec S., Aymonier C., Loppinet-Serani A., Weill F., Grosse S., Etourneau J., Cansell F.
}

Abstract :

In this study, the synthesis of nanostructured particles of nitrides $\left(\mathrm{Cr}_{2} \mathrm{~N}, \mathrm{Co}_{2} \mathrm{~N}, \mathrm{Fe}_{4} \mathrm{~N}, \mathrm{Cu}_{3} \mathrm{~N}, \mathrm{Ni}_{3} \mathrm{~N}\right)$, metal $(\mathrm{Cu})$ and oxides $\left(\mathrm{Al}_{2} \mathrm{O}_{3}\right.$, $\mathrm{TiO}_{2}, \mathrm{Ga}_{2} \mathrm{O}_{3}$ ) by using supercritical ammonia in the reaction medium is described. The elaboration process is based on the thermal decomposition of metal precursors in a supercritical ammonia-methanol mixture at a range of temperatures between 170 and $290^{\circ} \mathrm{C}$ at about $16 \mathrm{MPa}$. Nitrides are obtained at relatively low temperatures in comparison with classical processes. It is shown that the chemical composition of the produced materials can be controlled by the adjustment of process operating conditions (pressure, temperature, metal precursor concentration and residence time in the elaboration reactor) and by the knowledge of the Gibbs free energy of oxide formation of the studied metal.

\section{Introduction :}

Today one of the main challenges in materials science concerns the synthesis of nanomaterials since they exhibit interesting properties which can be different of those of bulk materials. For instance, optical, magnetic and electrical properties are sensitive to size effects. Furthermore nanosized particles are equally very efficient in the field of catalysis due to high ratio of surface to volume. Consequently, numerous processes of nanomaterial synthesis have been investigated aiming to control their size, morphology, structure and chemical composition.

In this context, supercritical processes are an interesting alternative to elaborate nanomaterials. A large number of studies concerning the production of nanoparticles have been published. There exist two main routes of material elaboration in supercritical media: processes using a physical transformation (rapid expansion of supercritical solution, gas antisolvent, $)^{1-4}$ and less commonly processes using a chemical transformation. ${ }^{5-8}$ This work refers to the chemical transformation of metal precursors in a supercritical fluid. More precisely the metal precursor is thermally decomposed to metal atoms which give access to the nucleation and growth of particles.
Previous works devoted to copper particle synthesis in a supercritical mixture $\mathrm{CO}_{2}$-ethanol demonstrated that this process allows control of the size, the size distribution and the morphology of particles as a function of the operating conditions. ${ }^{9}$ In this paper, our objective is to demonstrate the potential of this process to also control the chemical composition of materials.

Many studies have concerned oxide synthesis in supercritical media such as oxide elaboration by hydrothermal synthesis $\left(\mathrm{CeO}_{2} \text { and } \mathrm{LiCoO}_{2}\right)^{5,10,11}$ or the synthesis of $\mathrm{MgAl}_{2} \mathrm{O}_{4}$ in supercritical ethanol.12 In addition, synthesis of metal particles by supercritical fluid processing has been equally studied: (i) preparation of nickel, cobalt and iron nanoparticles by chemical reduction of $\mathrm{NiCl}_{2}, \mathrm{CoCl}_{2}$ and $\mathrm{FeBr}_{3}$, respectively; ${ }^{13}$ (ii) copper and silver nanoparticle synthesis in reverse micelles in compressed propane and supercritical ethane solutions; ${ }^{14,15}$ (iii) synthesis of silver and copper nanoparticles in a water-insupercritical carbon dioxide microemulsion by chemical reduction of $\mathrm{Ag}^{+}$and $\mathrm{Cu}^{2+}{ }^{216}$ (iv) the reactive supercritical fluid spray fluid processing method for silver nanoparticles elaboration; ${ }^{17}$ (v) radiolytically induced synthesis of silver nanoparticles in supercritical ethane; ${ }^{18}$. Finally, nitride synthesis has been investigated to a lesser extent: (i) the synthesis of $\mathrm{TiN}$ in supercritical cryogenic nitrogen by self-propagating-hightemperature synthesis $\left(6.21 \mathrm{MPa},-141^{\circ} \mathrm{C}\right) ;^{19}$ (ii) GaN synthesis by an ammonothermal process (100-500 MPa, $\left.550{ }^{\circ} \mathrm{C}\right) ;{ }^{20}$ (iii) solvothermal synthesis of $\mathrm{GaN}$ in supercritical ammonia (100-250 MPa, $\left.400-800{ }^{\circ} \mathrm{C}\right) ;{ }^{21}$ (iv) elaboration of $\mathrm{Ni}_{3} \mathrm{~N}$ in supercritical ammonia from $\mathrm{Ni}\left(\mathrm{NH}_{3}\right)_{6} \mathrm{Cl}_{2}\left(\mathrm{NaNH}_{2}, 250{ }^{\circ} \mathrm{C}\right.$ and $\left.200 \mathrm{MPa}\right){ }^{22}$

In this paper we propose to study the influence of process operating conditions on the control of material nature, and more precisely, on nanostructured nitride elaboration in supercritical ammonia. After a brief description of the experimental set-up and operating conditions, the different types of obtained nanostructured materials as a function of process operating conditions are described.

Experimental : 


\section{Experimental set-up}

The experimental set-up is a continuous process (Fig. 1). It is composed of two pumps: one for pumping a solvent $\left(\mathrm{NH}_{3}\right.$ or $\mathrm{CO}_{2}$ ), the other for pumping a cosolvent (methanol or ethanol) to dissolve the metal precursor. The decomposition reaction occurs inside the reactor which is maintained at constant pressure and temperature. The particles elaborated in the reactor are dragged by the flowing fluid to a second vessel (the collector) placed at the outlet of the reactor. In the collector, the particles are stopped by a metal filter placed perpendicularly to the fluid flow. At the end of the experiment, the powder is collected. The powders were dry and free of solvent.

\section{Experiments :}

The experimental conditions are summarized in Table 1. Ammonia was chosen as the reaction medium, except for experiment 1 , since it exhibits a high reducing power and its critical temperature $\left(T_{\mathrm{C}}=132.4^{\circ} \mathrm{C}\right.$ and $\left.P_{\mathrm{C}}=11.29 \mathrm{MPa}\right)$ is lower than that of precursor decomposition (most of the metal precursors are thermally decomposed at temperatures above 200 ${ }^{\circ} \mathrm{C}$ ). Methanol is used as cosolvent (molar ratio: $70 \% \mathrm{NH}_{3}-30 \%$ methanol) in order to solubilize the metal precursor and to decrease its decomposition temperature (reducing agent).

In the reaction media, there are always traces of oxygen. More precisely, the potential sources of oxygen are: the cosolvent (methanol) and metal precursors (of the acetylacetonate family). The total flow rate was of $1.02 \mathrm{I} \mathrm{h}^{-1}$. Experiment 1 was performed in a supercritical mixture of $\mathrm{CO}_{2}$-ethanol.

Three types of metal precursors were tested: metal acetylacetonates (acac), metal hexafluoroacetylacetonates (hfac) and a metal diisopropoxide bis(acetylacetonate) $\left(\mathrm{OPr}_{2}\right)_{2}(\mathrm{acac})_{2}$. All these precursors were provided by Sigma-Aldrich or Strem and used without any further purification. Experimental pressures were about $16 \mathrm{MPa}$ and temperatures between 180 and $290{ }^{\circ} \mathrm{C}$ as a function of decomposition temperatures of studied metal precursors.

\section{Characterization}

The chemical nature of materials was identified by conventional X-ray powder diffraction (XRPD: Cu-K $\alpha$ radiation). When crystallized domains were too small to be detected by $X R D$, electron diffraction was used (JEOL 2000FX microscope); samples were prepared by deposition of a drop of powder dispersed in ethanol on a copper carbon grid. The particle size and morphology were investigated by scanning electron microscopy, SEM (JEOL 840 microscope) and by transmission electron microscopy using the dark field method. The particle size was determined by manual counting.

In a few cases, the materials were amorphous and a thermal treatment was performed from 20 to $1000{ }^{\circ} \mathrm{C}$ under argon in a tubular furnace. The thermal treatment led to the crystallization of amorphous materials. The obtained crystalline powder can be characterized by the above methods.

\section{Results and discussion :}

\section{Results}

The results, structure, chemical composition, morphology and size of crystallized domains of the obtained materials are given in Table 2.

In the case of copper hexafluoroacetylacetonate, the chemical composition of recovered materials depends on the fluid nature. $\mathrm{CO}_{2}$-ethanol $\left(200{ }^{\circ} \mathrm{C}-20 \mathrm{MPa}\right.$ ) leads to spherical metal copper particles of few micrometers diameter constituted of crystalline nanodomains of about $10 \mathrm{~nm}$ (Fig. 2(a)) whilst in $\mathrm{NH}_{3}$-methanol $\left(200{ }^{\circ} \mathrm{C}-16 \mathrm{MPa}\right)$, cubic copper nitride monocrystals $(10 \mu \mathrm{m})$ were obtained (Fig. 2(b)). The difference of morphology between the metal and nitride has already been discussed ${ }^{9}$ and is due to the initial concentration of copper precursor as explained elsewhere.

The synthesis of materials in supercritical $\mathrm{NH}_{3}-$ methanol from nickel and cobalt precursors leads to the pure metal nitrides: nickel nitride and cobalt nitride. As far as $\mathrm{Ni}_{3} \mathrm{~N}$ and $\mathrm{Co}_{2} \mathrm{~N}$ particles were concerned, they are organized in shapeless aggregates of a few micrometers constituted of crystalline nanodomains of 20100 and $60-120 \mathrm{~nm}$, respectively. These materials were identified by XRD and electron diffraction (Fig. 3).

The decomposition of iron and chromium precursors in supercritical $\mathrm{NH}_{3}$-methanol induces the formation of oxide/nitride mixtures, more precisely, $\mathrm{Fe}_{2} \mathrm{O}_{3} / \mathrm{Fe}_{4} \mathrm{~N}$ and $\mathrm{Cr}_{2} \mathrm{O}_{3} / \mathrm{Cr}_{2} \mathrm{~N}$, as shown in Fig. 4. The mixture $\mathrm{Fe}_{2} \mathrm{O}_{3} / \mathrm{Fe}_{4} \mathrm{~N}$ is composed of crystalline nanodomains of $10 \mathrm{~nm}$ aggregated in spherical particles of 50 $\mathrm{nm}$, so the chemical composition was identified by electron diffraction (Fig. 4). Concerning the second mixture, $\mathrm{Cr}_{2} \mathrm{O}_{3} / \mathrm{Cr}_{2} \mathrm{~N}$, it was amorphous after the synthesis thus a thermal treatment was 
performed. The obtained material was crystallized and characterized by XRD (Fig. 4(b)). A mixture of $\mathrm{Cr}_{2} \mathrm{O}_{3}$ and $\mathrm{Cr}_{2} \mathrm{~N}$, was synthesized with two different chromium precursors: chromium(III) acetylacetonate and chromium(III) hexafluoroacetylacetonate. Oxides were obtained by decomposition of gallium, titanium and aluminium precursors under the same experimental conditions (supercritical $\mathrm{NH}_{3}-$ methanol). These decompositions were performed at 225-230 ${ }^{\circ} \mathrm{C}, 16 \mathrm{MPa}$ (Table 1) and led to the growth of $\mathrm{Ga}_{2} \mathrm{O}_{3}, \mathrm{TiO}_{2}$ and $\mathrm{Al}_{2} \mathrm{O}_{3}$, respectively. The $\mathrm{Ga}_{2} \mathrm{O}_{3}$ and $\mathrm{TiO}_{2}$ powders are formed by aggregated crystalline nanodomains of $1-10$ and $4-50 \mathrm{~nm}$, respectively, as shown in Fig. 5.

In contrast to the above oxides, aluminium oxide was amorphous. The $\mathrm{Al}_{2} \mathrm{O}_{3}$ particles were spherical particles of about $2 \mu \mathrm{m}$ (Fig. 6(a)). A thermal treatment was applied to the amorphous material and led to well crystallized aluminium oxide particles as shown in Fig. 6(b).

\section{Discussion :}

The choice of the solvent has a great influence on the chemical composition of materials as demonstrated above between syntheses in $\mathrm{CO}_{2}$ (metallic copper) and $\mathrm{NH}_{3}$ (copper nitride). $\mathrm{CO}_{2}$ is an inert solvent whereas $\mathrm{NH}_{3}$ reacts with the metal atoms to give nitrides. This process of material elaboration in supercritical ammonia allows nitrides to be obtained, in a controlled manner, at relatively low temperature and pressure in comparison with other published methods. ${ }^{23,24}$

Beyond the case of copper, metal nitride formation does not depend only on the solvent choice but also on the nature of the metal. In fact three different behaviours have been observed: nitride formation $\left(\mathrm{Cu}_{3} \mathrm{~N}, \mathrm{Ni}_{3} \mathrm{~N}\right.$ and $\left.\mathrm{Co}_{2} \mathrm{~N}\right)$, mixture oxide/nitride formation $\left(\mathrm{Fe}_{2} \mathrm{O}_{3} / \mathrm{Fe}_{4} \mathrm{~N}\right.$ and $\left.\mathrm{Cr}_{2} \mathrm{O}_{3} / \mathrm{Cr}_{2} \mathrm{~N}\right)$ and oxide formation $\left(\mathrm{Ga}_{2} \mathrm{O}_{3}, \mathrm{TiO}_{2}\right.$ and $\left.\mathrm{Al}_{2} \mathrm{O}_{3}\right)$.

To better understand these results, the affinity of the different studied metals with oxygen was quantified from an Ellingham diagram of oxide formation (Fig. 7). This diagram was obtained from the literature ${ }^{25}$ and was completed by the calculation of the curve relative to the formation of $\mathrm{Ga}_{2} \mathrm{O}_{3} \cdot{ }^{26}$ This diagram is established at atmospheric pressure but it can be used under our pressure conditions. The pressure dependence of the Gibbs free energy is given by eqn. (1):

$$
\Delta G(P)=\Delta G\left(P_{0}\right)+\Delta V P
$$

with $\Delta G(P)$, the Gibbs free energy at pressure $P, \Delta G\left(P_{0}\right)$, the Gibbs free energy at pressure $P_{0}$ and $\Delta V$, the molar volume.

Furthermore, $\Delta V$ is inversely proportional to the Young modulus of the concerned oxide and so can be neglected; in these conditions, we can assume $\Delta G(P) \approx \Delta G\left(P_{0}\right)$.

On the one hand, metals for which the Gibbs free energy of oxide formation is weak ( $\mathrm{Cu}, \mathrm{Ni}$ and $\mathrm{Co}$ ) tend to only give metal nitrides because the ammonolysis reaction is favoured relative to the metal oxidation reaction by the oxygen atoms dissolved in the reaction media. On the other hand, metals for which the Gibbs free energy of oxide formation is high ( $\mathrm{Ti}$ and $\mathrm{Al}$ ) lead to metal oxides.

As far as iron and chromium were concerned, these are located in an intermediate range of affinity with oxygen and there is a competition between ammonolysis and oxidation which involves the formation of mixtures $\mathrm{Cr}_{2} \mathrm{O}_{3} / \mathrm{Cr}_{2} \mathrm{~N}$ and $\mathrm{Fe}_{2} \mathrm{O}_{3} / \mathrm{Fe}_{4} \mathrm{~N}$.

The affinity of gallium with oxygen is in the same range as that of iron and chromium, but only the oxide was obtained. The kinetics of the gallium oxidation reaction seems to be favoured in regard to the thermodynamics.

\section{Conclusions :}

Beyond the control of size, size distribution and morphology, the process of material preparation in supercritical media, developed at ICMCB, allows to control the chemical composition of the synthesized nanostructured materials. This process is based on the thermal decomposition of metal precursors in supercritical media, more precisely, in a supercritical ammonia-methanol mixture used in this study.

The thermal decomposition in supercritical ammonia-methanol mixtures of different metal precursors (precursors of $\mathrm{Cu}, \mathrm{Ni}, \mathrm{Co}$, $\mathrm{Fe}, \mathrm{Cr}, \mathrm{Ga}, \mathrm{Al}$ and $\mathrm{Ti}$ ) was studied at a range of temperatures between 170 and $290{ }^{\circ} \mathrm{C}$ at about $16 \mathrm{MPa}$. Three different mechanisms were observed with the formation of nitrides $\left(\mathrm{Cr}_{2} \mathrm{~N}\right.$, $\left.\mathrm{Co}_{2} \mathrm{~N}, \mathrm{Cu}_{3} \mathrm{~N}, \mathrm{Ni}_{3} \mathrm{~N}, \mathrm{Fe}_{4} \mathrm{~N}\right)$, metal $(\mathrm{Cu})$ and oxides $\left(\mathrm{Al}_{2} \mathrm{O}_{3}, \mathrm{TiO}_{2}\right.$, $\mathrm{Ga}_{2} \mathrm{O}_{3}$ ). In most of the experiments, the synthesized powders were composed of crystalline nanodomains $(<100 \mathrm{~nm})$ aggregated in spherical or shapeless particles (except for the $\mathrm{Cr}$ 
and Al compounds which were amorphous).

Thus, the use of supercritical ammonia in the reaction media allows the elaboration of nitrides at relatively low temperatures if the Gibbs free energy of oxide formation of the metal is not too high ( $\mathrm{Cr}, \mathrm{Co}, \mathrm{Cu}, \mathrm{Ni}$ and $\mathrm{Fe}$ ). By contrast, only oxides are obtained with metals for which the Gibbs free energy of oxide formation is high ( $\mathrm{Al}$ and $\mathrm{Ti}$ ).

\section{Acknowledgements :}

We would like express our thanks to CREMEMs staff for recording all the TEM and SEM images.

\section{References :}

1 / Y. Komai, H. Kasai, H. Hirakoso, Y. Hakuta, S. Okada, H. Oikawa, T. Adschiri, H. Inomata, K. Arai and H. Nakanishi, Mol. Cryst. Liq. Cryst., 1998, 322, 167.

2 / Y. Komai, H. Kasai, H. Hirakoso, Y. Hakuta, H. Katagi, S. Okada, H. Oikawa, T. Adschiri and H. Inomata, Jpn. J. Appl. Phys., 1999, 38, L81.

3 / E. Reverchon, G. D. Porta, D. Sannino and P. Ciambelli, Powder Technol., 1999, 102(2), 129.

4 / J. Jung and M. Perrut, J. Supercrit. Fluids, 2001, 20(3), 179.

5 / Y. Hakuta, S. Onai, H. Terayama, T. Adschiri and K. Arai, J. Mater. Sci. Lett., 1998, 17, 1211.

6 / Y. Hakuta, K. Seino, H. Ura, T. Adschiri, H. Takizawa and K. Arai, J. Mater. Chem., 1999, 9, 2671.

7 / T. Adschiri, Kona (Hirakata Jpn.), 1998, 16, 89.

8 / F. Cansell, B. Chevalier, A. Demourgues, J. Etourneau, C. Even, Y. Garrabos, V. Pessey, S. Petit, A. Tressaud and F. Weill, J. Mater. Chem., 1999, 9, 67.

9 / V. Pessey, R. Garriga, F. Weill, B. Chevalier, J. Etourneau and F. Cansell, J. Mater. Chem., 2002, $12(4), 958$.

10 / T. Adschiri, Y. Hakuta and K. Arai, Ind. Eng. Chem. Res., 2000, 39(12), 4901.

11 / T. Adschiri, Continuous hydrothermal synthesis of metal oxides in sub- and supercritical water, in International conference on processing materials for properties, Minerals, Metals and Materials Society, San Francisco, CA, 2000. 12C. Amiens, D. de Caro, B. Chaudret, J. S. Bradley, R. Mazel and C. Roucau, J. Am. Chem. Soc., 1993, 115, 11638.

13 / Y.-P. Sun, H. W. Rollins and R. Guduru, Chem. Mater., 1999, 11(1), 7.

14J / . P. Cason and C. B. Roberts, J. Phys. Chem. B, 2000, 104(6), 1217.

15 / J. P. Cason, K. Khambaswadkar and C. B. Roberts, Ind. Eng. Chem. Res., 2000, 39(12), 4749.

16 / H. Ohde, F. Hunt and C. M. Wai, Chem. Mater., 2001, 13(11), 4130.

17 / H. W. Rollins, Reactive supercritical fluid preparation of metal and metal-sulfide nanoparticles from carbon dioxide solutions, in 224th ACS National Meeting, American Chemical Society, Boston, MA, 2000.

18 / N. M. Dimitrijevic, K. Takahashi, D. M. Bartels and C. D. Jonah, Radiolytically induced synthesis of silver nanoparticles in supercritical ethane, in 222nd ACS National Meeting, American Chemical Society, Chicago, 2001.

19 / K. Brezinsky, J. A. Brehm, C. K. Law and I. Glassman, Supercritical combustion synthesis of titanium nitride, in Twenty-sixth symposium (International) on combustion, Napoli, Italy, July 28-August 2, ed. A. R. Burgers, The Combustion Institute, Pittsburgh, 1996, vol. 2, p. 1875.

20 / R. Dwilinski, A. Wysmolek, J. Baranowski, M. Kaminska, R. Doradzinski, J. Garczinski, L. Sierzputowski and H. Jacobs, Acta. Phys. Pol. A, 1995, 88(5), 833.

21 / C. Collado, G. Demazeau, B. Berdeu, A. Largeteau, J.-C. Garcia, J.-L. Guyaux and J. Massies, in Chimie de l'état solide et cristallochimie/Solid state chemistry and crystallochemistry, C. R. Acad. Sci., Ser. 2c: chim., Paris, 1999, p. 483.

22 / A. Leineweber, H. Jacobs and S. Hull, Inorg. Chem., 2001, 40, 5818. 
23 / F. Attar and T. Johannesson, Thin Solid Films, 1995, 258, 205.

24 / N. S. Gajbhiye, R. S. Ningthoujam and J. Weissmüller, Phys. Status Solidi A, 2002, 189(3), 691.

25 / J. Philibert, A. Vignes, Y. Bréchet and P. Combrade, Métallurgie du minerai au matériau, Masson, Paris, 1998.

26 / M. Stan, T. J. Armstrong, D. P. Butt, T. C. Wallace, Sr., Y. S. Park, C. L. Haertling, T. Hartmann and R. J. Hanrahan, Jr., J. Am. Ceram. Soc., 2002, 85(11), 2811. 
$1 \mathrm{Cu}(\mathrm{hfac})_{2}$

$\mathrm{CO}_{2} \quad 4.1 \times 10^{-2}$

200

$2 \mathrm{Cu}(\mathrm{hfac})_{2}$

$\mathrm{NH}_{3} \quad 4 \times 10^{-3}$

200

$3 \mathrm{Ni}(\mathrm{hfac})_{2}$

$\mathrm{NH}_{3} \quad 4 \times 10^{-3}$

290

$4 \mathrm{Co}(\mathrm{hfac})_{2}$

$\mathrm{NH}_{3} \quad 4 \times 10^{-3}$

260

$5 \mathrm{Fe}(\mathrm{acac})_{3}$

$\mathrm{NH}_{3} \quad 4 \times 10^{-3}$

180

$6 \quad \mathrm{Cr}(\mathrm{hfac})_{3}$

$\mathrm{NH}_{3} \quad 2 \times 10^{-3}$

260

$7 \quad \mathrm{Cr}(\text { acac })_{3}$

$\mathrm{NH}_{3} \quad 4 \times 10^{-3}$

230

$8 \mathrm{Ga}(\mathrm{acac})_{3}$

$\mathrm{NH}_{3} \quad 1.7 \times 10^{-3}$

225

$9 \quad \mathrm{Al}(\mathrm{acac})_{3}$

$\mathrm{NH}_{3} \quad 4 \times 10^{-3}$

225

$10 \quad \mathrm{Ti}^{\left(\mathrm{OPr}^{\mathrm{i}}\right)_{2}(\mathrm{acac})_{2}}$

$\mathrm{NH}_{3} \quad 6 \times 10^{-3}$

230

Table 2 Chemical composition, structure, morphology and size of crystallized domains of synthesized nanostructured materials

Chemical

Test composition
Structure

Cubic, $a=3.6150 \AA$

Cubic, $a=3.8171 \AA$

$2 \mathrm{Cu}_{3} \mathrm{~N}$

$3 \quad \mathrm{Ni}_{3} \mathrm{~N}$

$4 \mathrm{Co}_{2} \mathrm{~N}$

$5 \quad \mathrm{Fe}_{2} \mathrm{O}_{3}+\mathrm{Fe}_{4} \mathrm{~N}$

Hexagonal, $a=4.6224 \AA, c=4.3059 \AA$

Orthorhombic, $a=2.8535 \AA, b=4.6056 \AA, c=$ $4.3443 \AA$

$6 \quad \mathrm{Cr}_{2} \mathrm{O}_{3}+\mathrm{Cr}_{2} \mathrm{~N}$

Cubic, $a=8.3515 \AA ;$ cubic, $a=3.7950 \AA$

Amorphous

$7 \quad \mathrm{Cr}_{2} \mathrm{O}_{3}+\mathrm{Cr}_{2} \mathrm{~N}$

Amorphous

$8 \quad \mathrm{Ga}_{2} \mathrm{O}_{3}$

$9 \quad \mathrm{TiO}_{2}$

$10 \quad \mathrm{Al}_{2} \mathrm{O}_{3}$
Monoclinic, $a=12.2271 \AA, b=3.0389 \AA, c=$ $5.8079 \AA, \beta=103.82^{\circ}$

Tetragonal (rutile), $a=4.5933 \AA, c=2.9592 \AA$

Amorphous
Size of crystallized domains

$10 \mathrm{~nm}$ aggregates

Cubic monocrystals $10 \mu \mathrm{m}$

Shapeless aggregates

20-100 nm

Shapeless aggregates

Shapeless aggregates

Shapeless aggregates

Shapeless aggregates

Shapeless aggregates

$60-120 \mathrm{~nm}$

$5-60 \mathrm{~nm}$

Shapeless

aggregates

Spherical particles - 


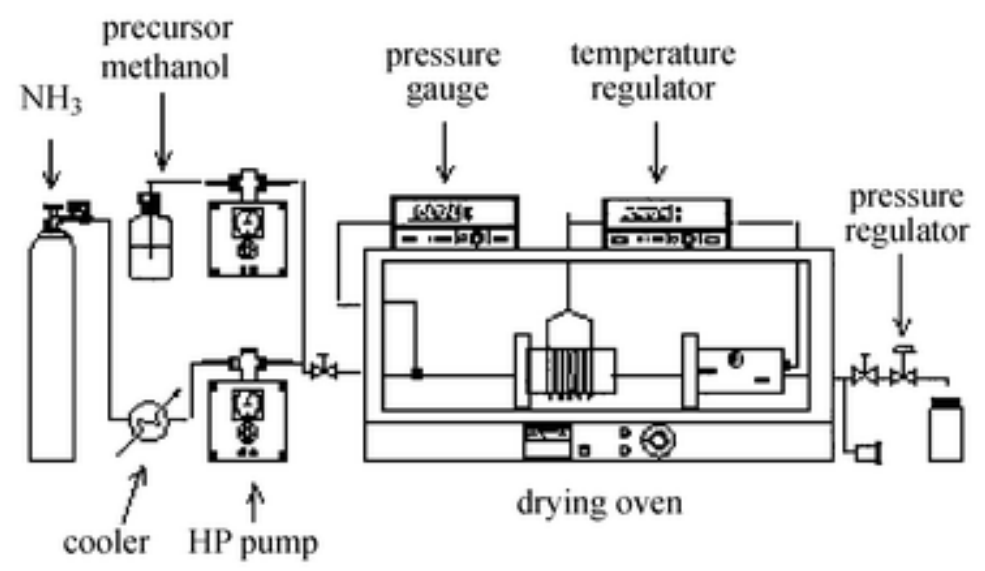

Fig. 1 Experimental set-up for material synthesis in supercritical fluid.

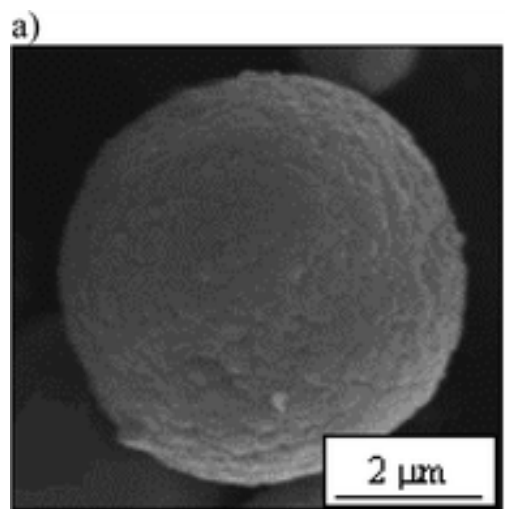

b)

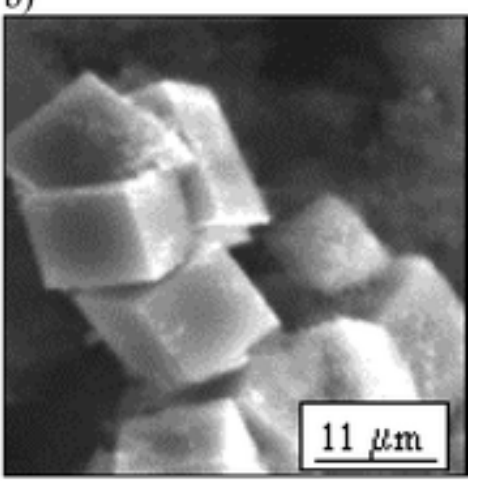

Fig. 2 Influence of reaction media on the particle chemical composition: (a) SEM image of a spherical nanostructured copper particle, (b) SEM image of cubic copper nitride monocrystals. 


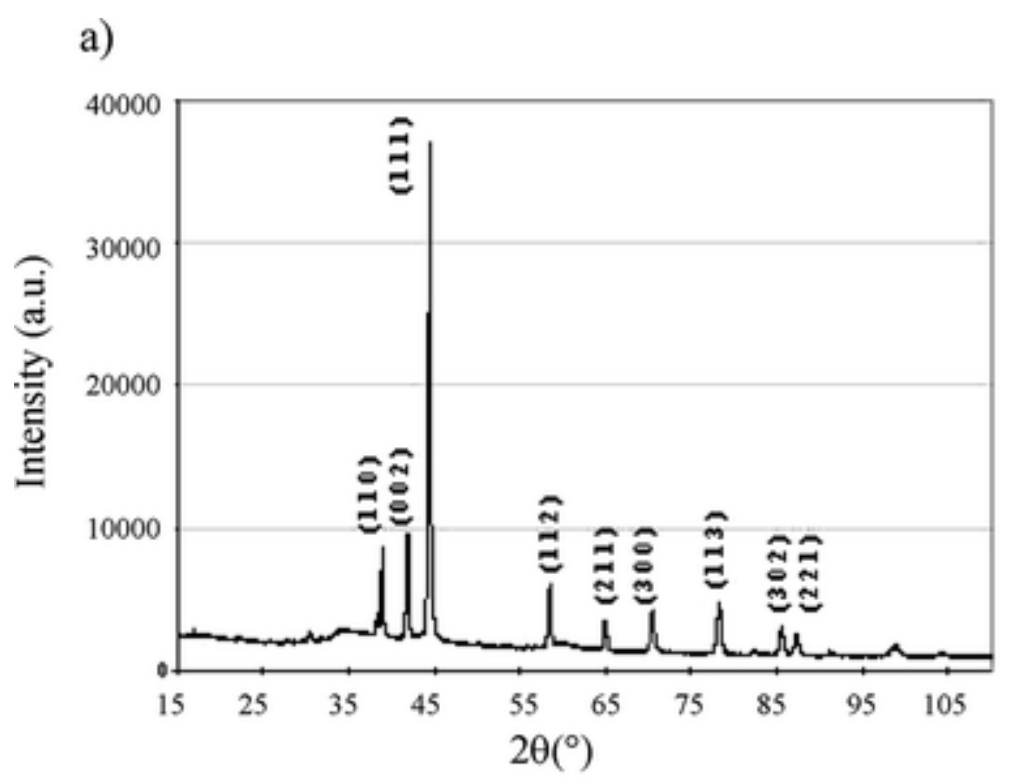

b)

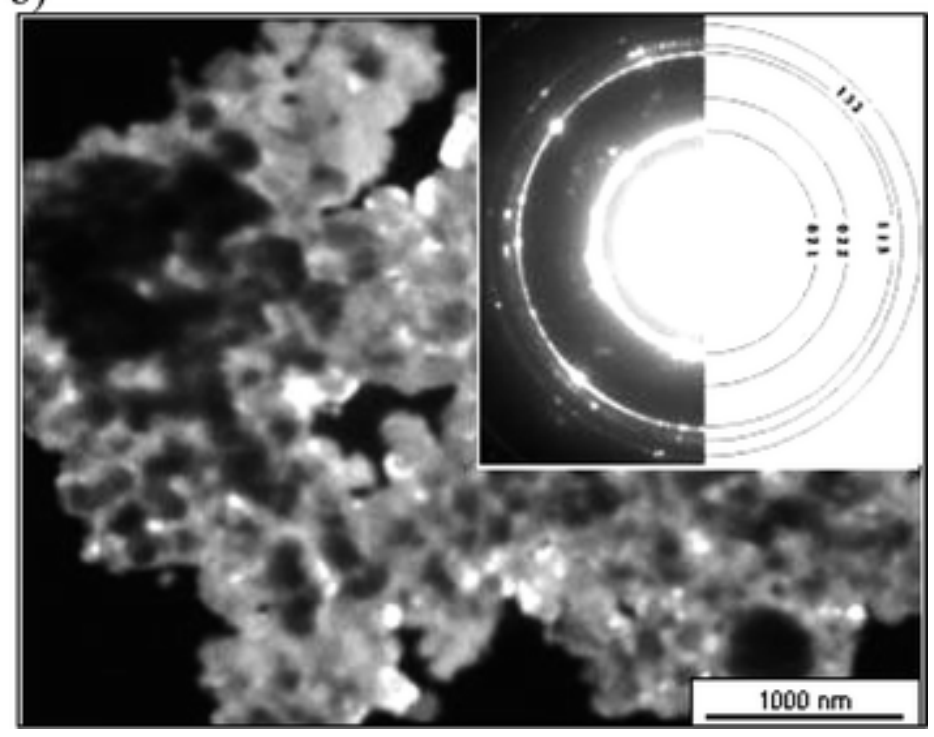

Fig. 3 (a) XRD pattern of $\mathrm{Ni}_{3} \mathrm{~N}$ and (b) microscopic and electronic characterization of $\mathrm{Co}_{2} \mathrm{~N}$. 
a)

b)
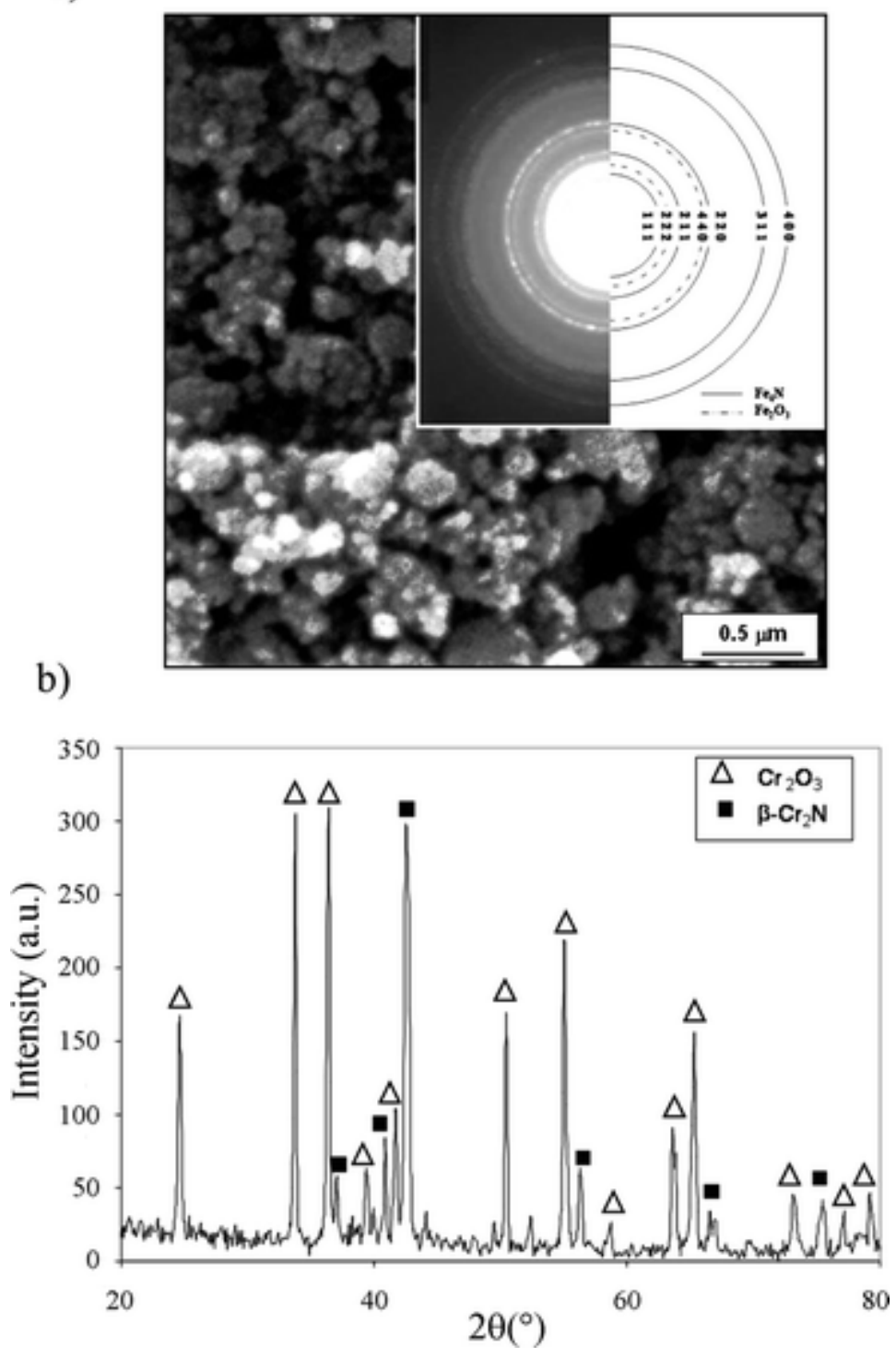

Fig. 4 Structural characterization of mixtures $\mathrm{Fe}_{2} \mathrm{O}_{3} / \mathrm{Fe}_{4} \mathrm{~N}$ and $\mathrm{Cr}_{2} \mathrm{O}_{3} / \mathrm{Cr}_{2} \mathrm{~N}$ : (a) electron diffraction pattern and SEM image of $\mathrm{Fe}_{2} \mathrm{O}_{3} / \mathrm{Fe}_{4} \mathrm{~N}$, (b) XRD pattern of $\mathrm{Cr}_{2} \mathrm{O}_{3} / \mathrm{Cr}_{2} \mathrm{~N}$. 
a)

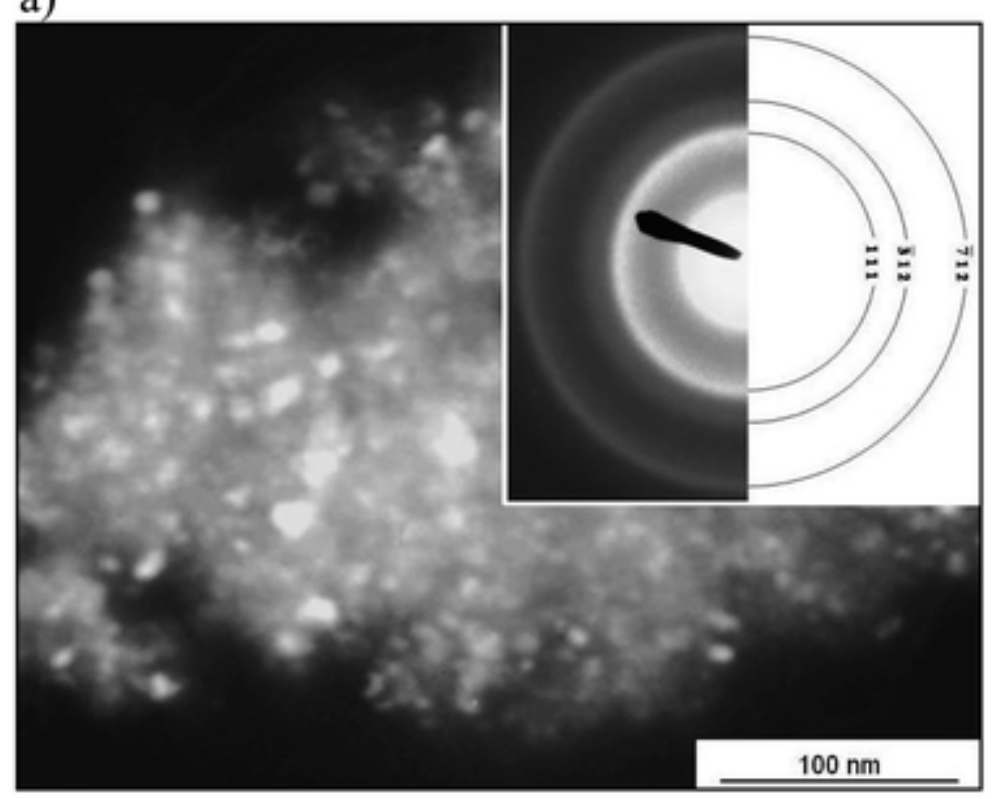

b)

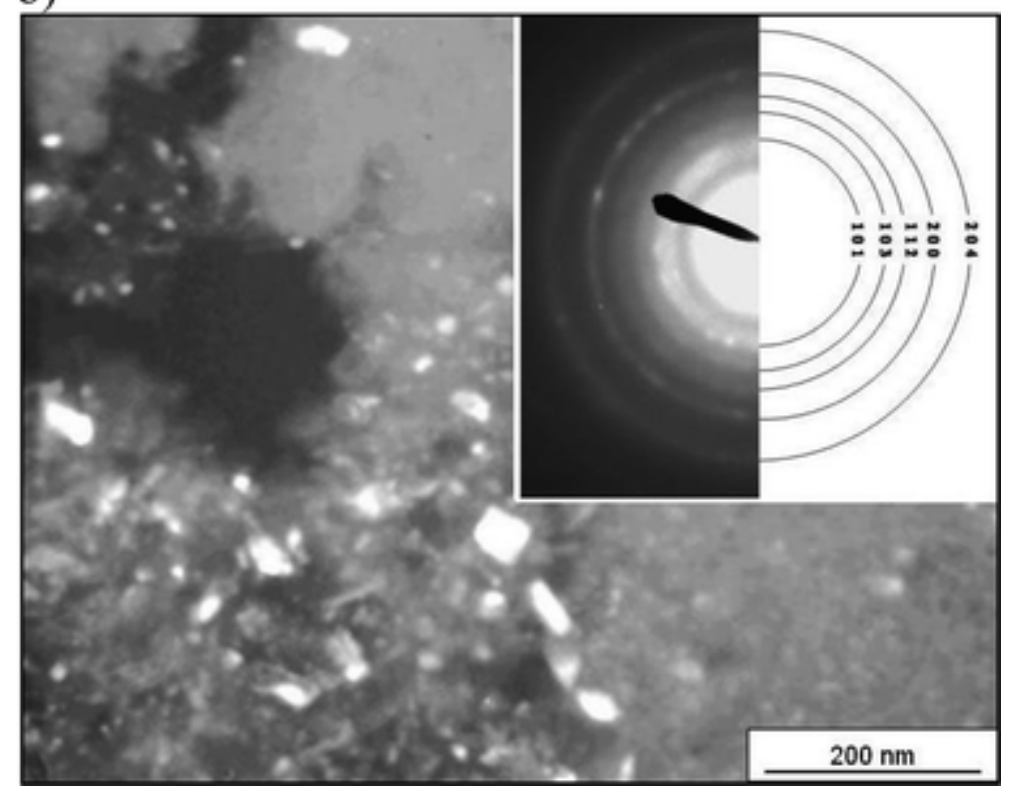

Fig. 5 TEM images and electron diffraction patterns of (a) $\mathrm{Ga}_{2} \mathrm{O}_{3}$ and (b) $\mathrm{TiO}_{2}$. 
a)

b)
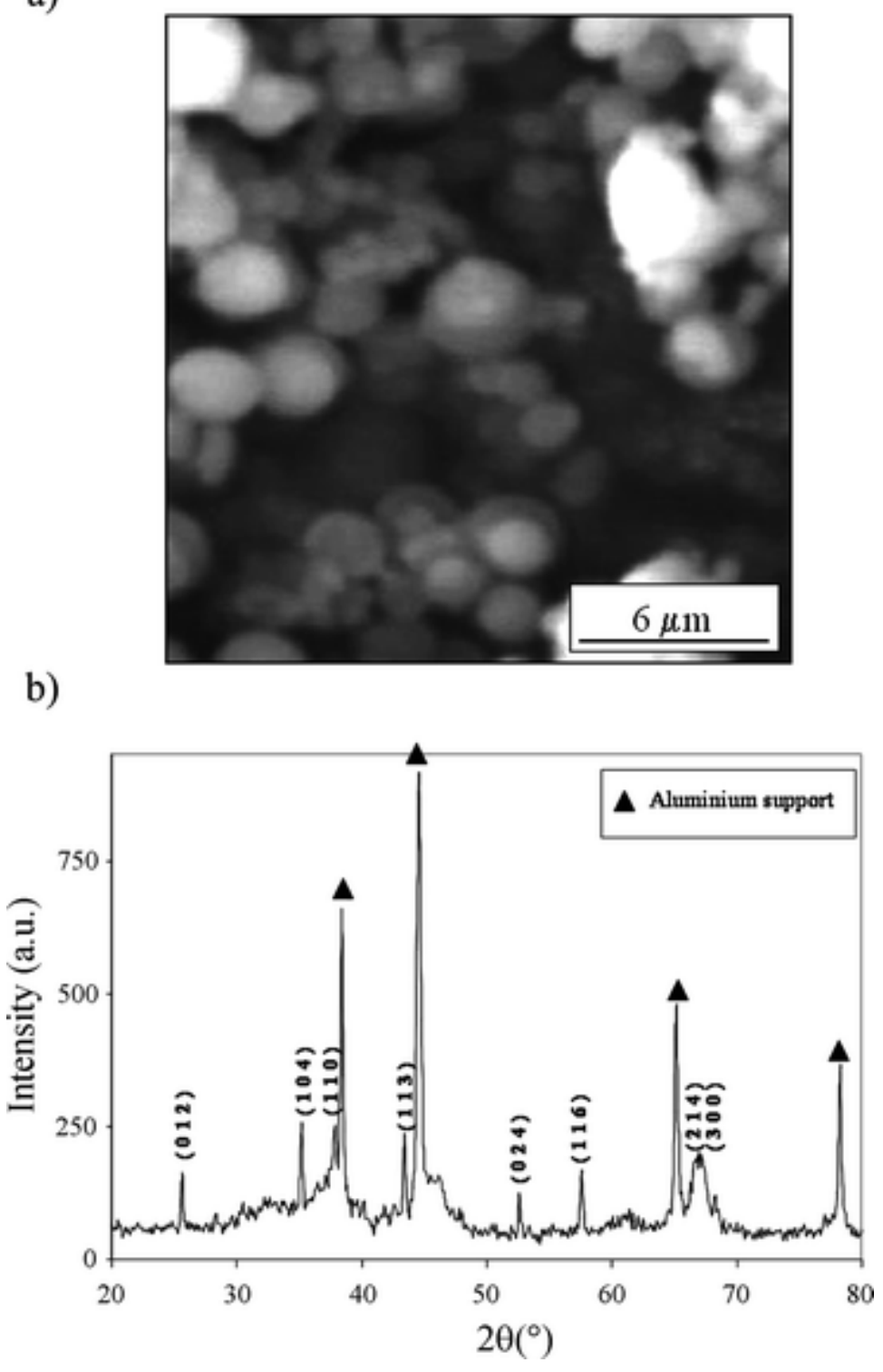

Fig. $6 \mathrm{SEM}$ image of amorphous $\mathrm{Al}_{2} \mathrm{O}_{3}$ (after synthesis) and XRD pattern of crystallized $\mathrm{Al}_{2} \mathrm{O}_{3}$ (after thermal treatment). 


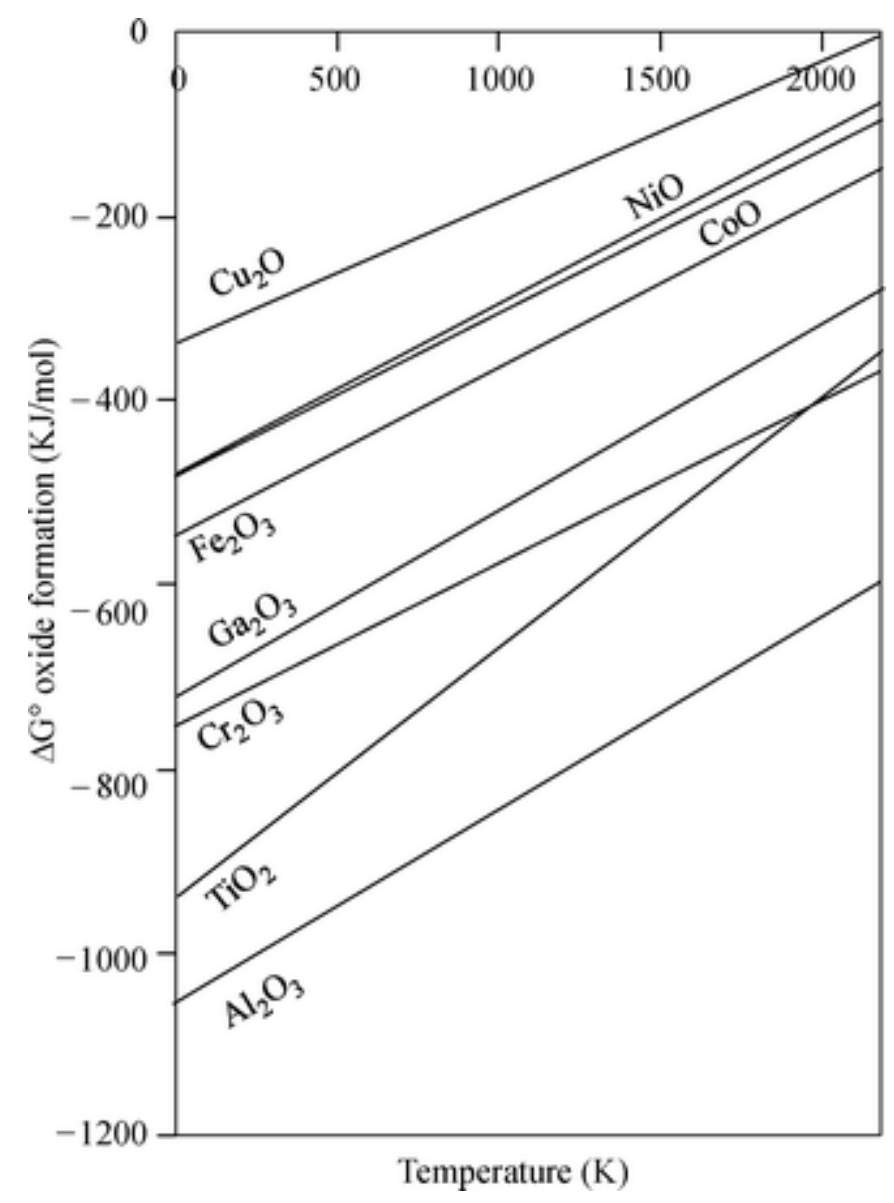

Fig. 7 Ellingham diagram of oxide formation. 